DOI https://doi.org/10.36059/978-966-397-240-4-11

Семенченко О. Л.

кандидат сільськогосподарських наук, доцент, доцент кафедри селекції і насінництва Дніпровський державний аграрно-економічний університет м. Дніпро

\title{
ТЕХНОЛОГІЧНІ АСПЕКТИ ВИРОЩУВАННЯ КАРТОПЛІ РАННЬОЇ НА ЗРОШЕННІ В ЗОНІ ПІВНІЧНОГО СТЕПУ УКРАЇНИ: ЗА УЩІЛЬНЕННЯ ПОСІВІВ ТА У ДВОУРОЖАЙНІЙ КУЛЬТУРІ
}

Анотація. До новітніх технологій у рослинництві відноситься вирощування картоплі ранньої (молодої) в ущільнених посівах та двоурожайній культурі для весняного та літньо - осіннього споживання. Проблематика виробництва картоплі ранньої (молодої) в зоні північного Степу України полягає у природно кліматичних умовах вирощування (зона недостатнього зволоження з жарким та спекотним літом і холодними зимами), проте на зрошуваних землях культура картоплі дає значні врожаї дієтичної продукції високої якості. Ущільнення посівів на основі алелопатичних взаємозв'язків рослин дає можливість додатково одержати урожай супутніх культур $і$ більш раціонально використати поливні землі. Недозрілі (молоді) бульби картоплі поживний та дієтичний продукт, що користується попитом на ринку, в літньо - осінні місяці даної продукції власного виробництва на ринку майже немає, вирощування у двоурожайній культурі дає можливість задовольнити попит ринку на дану продукцію.

\section{Вступ}

Щорічно в Україні вирощують 19,5 млн тонн картоплі (з них на ранню продукцію припадає близько 35-40\%) за потреби внутрішнього ринку 20-22 млн тонн на рік. Попит на ранню продукцію задовольняється шляхом імпорту з Єгипту, Голландії, Польщі, яка потрапляє під визначення «молода картопля». Молода картопля відрізняється не тільки смаковими якостями, а й високою дієтичною цінністю. Ї̈̈ бульби містять білки та незамінні амінокислоти, які добре засвоюються організмом людини. Строк зберігання молодої картоплі - до п’яти діб, далі в ній відбуваються 
незворотні фізіологічні процеси (старіння), бульби поступово дозрівають і втрачають свою харчову цінність. Оскільки в Україні картопля рання весняного строку вирощування збирається в червні $\epsilon$ можливість ефективного використання зрошуваних земельних угідь шляхом повторного садіння картоплі зі свіжозібраних бульб у двоурожайній культурі для забезпечення ринку дієтичною продукцією власного виробництва наприкінці літа та восени. Розроблені елементи технології є додатковим способом розширення вживання молодої картоплі в осінні місяці 3 використанням свіжозібраних бульб, для чого встановлено різні способи їх пробудження, що дозволить забезпечити попит ринку, максимально ефективно використати зрошувані земельні угіддя та зміцнити економіку сільськогосподарських підприємств-виробників.

\section{1. Технологія ущільнення посівів картоплі ранньостиглої в умовах північного Степу України на зрошенні}

В зоні північного Степу України вирощування картоплі ранньої має декілька способів: в ущільнених посівах; весняного строку садіння з передсадивною обробкою бульб та яровізацією; літнього строку садіння у двоурожайній культурі.

Ущільнення посівів - це можливість отримати різноманітну овочеву продукцію, що відповідає стандартам якості на одній ділянці земельних угідь. Правильне поєднання овочевих культур (з урахуванням їх алелопатичних зв'язків) дає високі врожаї якісної продукції, як основної культури, так і її ущільнювача. Рання картопля $є$ дієтичним продуктом і ущільнення ії посівів дозволяє отримати додатковий прибуток від виробництва.

Загальноприйнята технологія вирощування картоплі ранньої в зоні північного Степу України - висаджування бульб за схемою $70 \times 20 \mathrm{~cm}$.

Проте на ранніх стадіях онтогенезу рослини картоплі не повністю використовують площу міжрядь, що знижує ефективність використання зрошуваних земель [1, с. 34].

Ущільнення посівів сільськогосподарських культур є одним 3 дієвих способів ефективного використання посівних площ, добрив, вологи i сонячної енергії. Однак вирішенню даної проблеми присвячена незначна кількість публікацій в літературних джерелах. За даними досліджень В. Дегтярьова [2, с. 30], В. Сосунова [3, с. 34], В. Сапожнікова [4, с. 41], Р. Недбала [5, с. 167], Н. Дідуха $[6$, c. 235], Т. Гарбовської [7, с. 53], 3. Сича [8, с. 28] при вирощуванні 
сільськогосподарських культур в умовах ущільнення посівів урожайність основних культур збільшувалась на 2-3 т/га. В окремих випадках урожайність залишалась на рівні контролю, при цьому сумарний врожай основних та ущільнюючих рослин 3 одиниці посівної площі підвищувався до 15-20 \% і залежав від зони вирощування та рослин ущільнювачів.

у високорозвинених країнах поширюються масштаби альтернативного землеробства, зокрема в овочівництві. В Інституті овочівництва і баштанництва НААН проводилися дослідження 3 розробки адаптивної (перехідної до органічної) системи виробництва овочевої продукції [9, с. 47], результати якого стали основою альтернативної (органічної) системи, а саме - задіяно метод інтеркропінгу (полікультури), що забезпечує створення умов для саморегулювання і самовідновлення агроекосистем.

Сучасне інтенсивне овочівництво має ряд серйозних екологічних проблем, пов'язаних 3 деградацією грунтів i виснаженням їx родючості. Овочі здавна використовують не тільки як звичайні продукти харчування, а й дієтичні та лікувальні. Саме тому необхідно піклуватися про їх високу якість, не допускати накопичення токсичних речовин. Для цього необхідний перехід від надмірної інтенсифікації до науково - обгрунтованої біологізації, методів органічногого землеробства (за європейською термінологією «альтернативне землеробство», за американською - «поновлюване землеробство») [10, с. 44].

Деякі овочі мають антимікробні властивості, отже, алелопатично пригнічують фітопатогенні гриби і бактерії. Для органічного землеробства алелопатія може бути важливим елементом в балансуванні відносин між густотою рослин і бур'янами, шкідниками, хворобами та сортами. Взаємозв'язки між видами рослин, зокрема змішані посіви, недостатньо вивчені, що $\epsilon$ вагомою причиною для проведення таких досліджень. [11, с. 275; 12, с. 167].

Більшість сільськогосподарських культур мають певну алелопатичну активність $[13$, с. $149 ; 14$, с. $177 ; 15$, с. 36]. Рослини виділяють в навколишнє середовище речовини різної біохімічної природи, які в ході складних хімічних перетворень грають важливу роль у формуванні «алелопатично нейтральних» систем - хімічно саморегульованих екосистем [16, с. $154 ; 17$, с. 109; 18, с. 151]. Вплив рослини - донора на рослину-акцептор шляхом алелопатичної взаємодії відрізняється за спрямованістю (стимулюючий, нейтральний 
або фітотоксичний) і за ступенем його прояву (сильноактивний, середньоактивний або малоактивний).

Для функціонування альтернативної системи за принципом інтеркропінгу (полікультури), на полі формуються смуги однакового розміру, кратні базовій колії трактора (наприклад 140 см). В одних смугах вирощують овочеві культури, в інших супутні. Чергування культур відбувається шляхом періодичної зміни цих смуг. Смуговий спосіб вирощування овочевих культур, на відміну від відомих розробок по полікультурних посівах, забезпечує повну технологічність виробничих процесів із застосуванням систем машин з різною шириною захвату агрегатів.

На підставі проведених біотестів (за методикою Гродзинського) [16, с 124], в лабораторних умовах, було виділено дві найбільш ефективні культури для ущільнення посівів картоплі в польових умовах - цибуля - шалот і салат. Проведеними дослідженнями встановлено, що вивчені рослини-донори за характером виділень відносяться до малоактивних по відношенню до проростання паростків картоплі. При цьому виявлено тенденцію до незначного їх стимулювання при пророщуванні з салатом і цибулею - шалот). Активність алелопатично - активних речовин в біопробі в умовних одиницях кумарину (УОК) за А. М. Гродзинським перебувала в межах 100-105. За шкалою Н. М. Матвєєва [19, с. 115]. ці рослини відносяться до алелопатично малоактивних (0 - 300 УОК).

Технологія вирощування картоплі ранньої загальноприйнята для північного Степу України. Різниця полягає в тому, що посадки основної культури (картопля) ущільнюють рослинами ущільнювачами. Картоплю висаджують у першій - другій декаді квітня 3 густотою 54-55 тис. рослин / га.

Ущільнюючу рослину (цибуля - шалот на зелене перо) висаджують в міжряддя картоплі відразу після її садіння на глибину 4-5 см за схемою $140 \times 8-10$ см (80-85 тис. рослин /га). За слідом коліс трактора ущільнення не проводити.

Догляд за посівами полягає у підживленнях, вегетаційних поливах та захисті рослин від шкідників і хвороб лише препаратими внесеними до діючого «Переліку пестицидів і агрохімікатів дозволених до використання в Україні».

Збирати цибулю - шалот на зелене перо слід при довжині листків 28-30 см не допускаючи їх огрубіння разом 3 цибулинами. Своєчасний збір врожаю рослин ущільнювачів дозволяє отримати повноцінний врожай картоплі ранньої та раніше звільнити ділянку для повторного вирощування інших овочевих рослин. 
Ущільнення картоплі цибулею - шалот і салатом не впливє на проходження фенологічних фаз рослинами картоплі - сходи незалежно від варіанту дослідження з'являються одночасно - через 24-25 діб після висаджування, цибулі - шалот і салату - через 12-14 діб. За біометричними показниками ущільнення цибулею шалот і салатом призводить до зниження висоти рослин картоплі, кількість стебел в кущі зменшується до 3,6 - 4,1 штуки на рослину рис. 1.

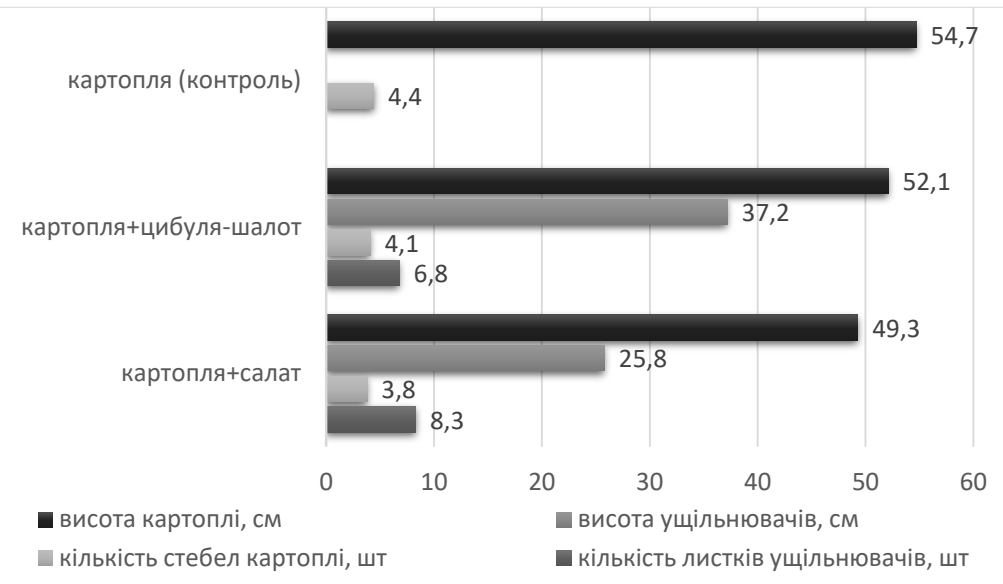

\section{Рис. 1 Біометричні показники рослин в ущільненому посіві}

Визначено, що врожайність ранньї (молодої) картоплі в чистому посіві, у середньому за три роки, становила 35,4 т/га, при ущільненні цибулею - шалот - 31,9 т/га, салатом - 30,5 т/га. Сумарний урожай відповідно склав: картопля + цибуля - шалот 42,1 т/га, картопля + салат - 46,8 т/га, тобто додаткова надбавка до контролю складає 18,9 і 32,2 \% відповідно. Додатково отримують урожай ущільнювачів, в середньому, цибулі - шалот - 10,2 т/га, салату - 16,3 т/га - рис. 2.

Структурний аналіз бульб картоплі вказує, що ущільнення впливає на формування бульб і товарність врожаю. Середня маса бульби у порівнянні 3 контролем знижується на 0,8 (ущільнення цибулею - шалот) - $2 \%$ (салат). Середня маса бульби становила відповідно від 109,2 до 123,4 м на контролі рис. 3. 


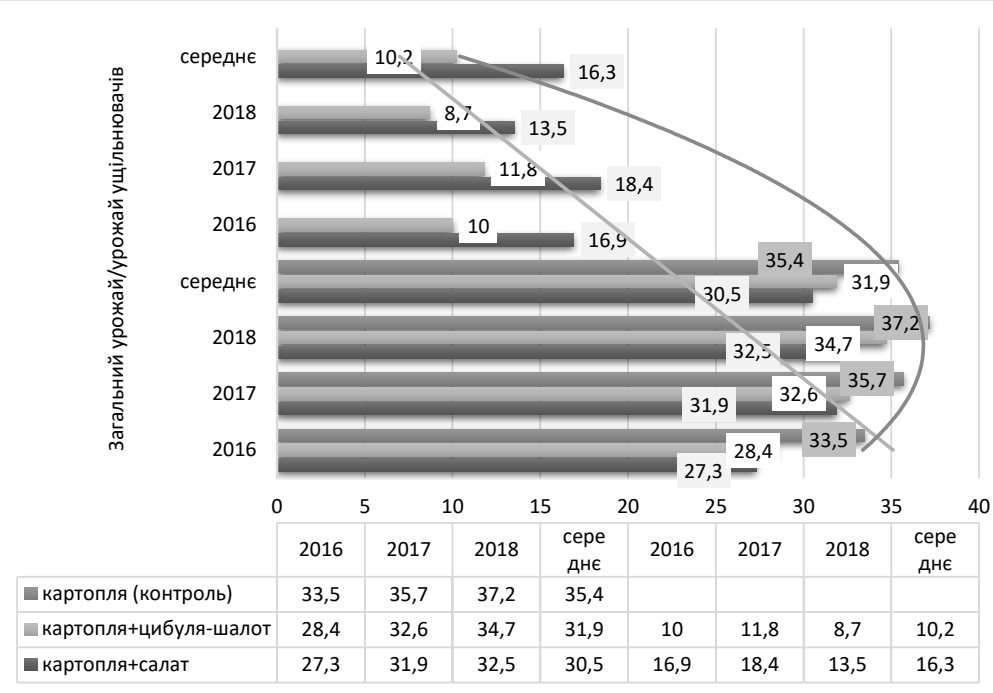

HIP 05, T/ra $-2,78$

Рис. 2. Врожайність картоплі ранньої та рослин-ущільнювачів

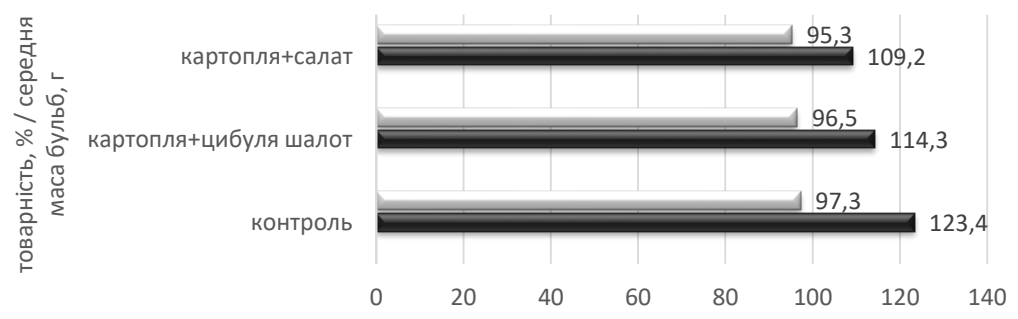

Рис. 3. Структурний аналіз врожаю бульб картоплі та його товарність в ущільнених посівах

Кращим ущільнювачем для ранньої картоплі $\epsilon$ цибуля - шалот на зелене перо (густота рослин 80-85 тис. рослин / га). Розроблений спосіб вирощування картоплі ранньої за ущільнення посівів цибулею - шалот сприяє підвищенню сумарного врожаю картоплі раннього і цибулі - шалот на 6,7 тонн з гектара. Рівень рентабельності становить $167 \%$ (для чистих посівів картоплі - $140 \%$ ) рис. 4. 


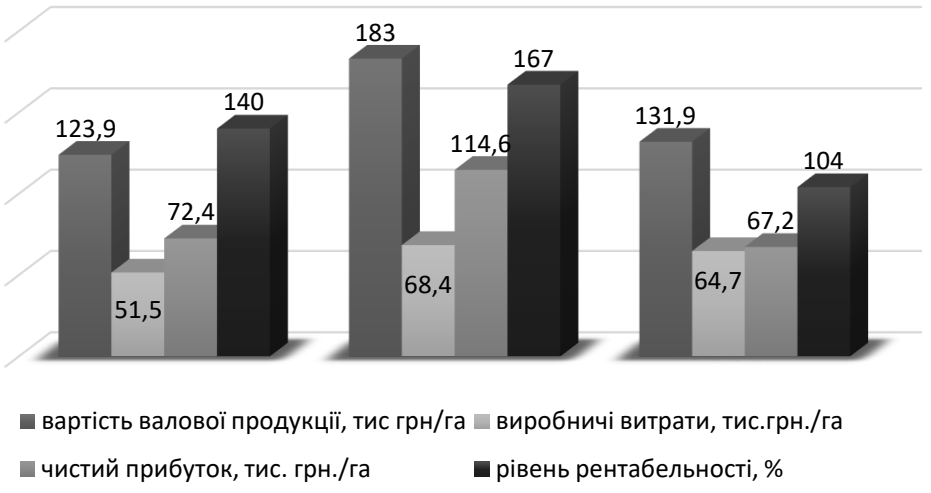

\title{
Рис. 4. Економічна ефективність виробництва картоплі ранньої в ущільнених посівах
}

\begin{abstract}
Виключне значення картоплі як продукту харчування пояснюється універсальністю іï використання для різних господарських цілей і в цьому ракурсі 3 картоплею не може зрівнятись жодна сільськогосподарська культура. За кількістю поживних речовин з одиниці площі картопля займає одне з перших місць серед рослин, що культивуються людиною. Калорійна цінність картоплі вдвічі вища за моркву, втричі за капусту, в чотири рази за томати. Картопляний білок (туберін) за біологічною цінністю кращий за рослинний білок ряду сільськогосподарських культур, зокрема пшениці [20, с. 207].
\end{abstract}

\section{2. Технологія картоплі ранньої (молодої) весняного строку} вирощування в зоні північного Степу України на зрошенні

Для збирання раннього врожаю (на 50 - ту добу від садіння) основні агротехнологічні аспекти:

- яровізація (пророщування) бульб впродовж 20 діб при t $12-16{ }^{\circ} \mathrm{C}$ та вологості повітря $75-80 \%$ НВ (сприяє підвищенню врожайності на 3,5 т/га та більше);

- локальне внесення мінеральних добрив у дозі $\mathrm{N}_{60} \mathrm{P}_{60} \mathrm{~K}_{30}$ (підвищення урожайності на 5,6 т/га і більше);

- передсадивна обробка бульб картоплі розчином сечовини (20 кг/т) (підвищення урожайності ранньої продукції від 4,4 т/га). 


\section{3. Яровізація (пророщування) посадкового матеріалу за весняного строку садіння}

Яровізація бульб - один з важливих технологічних прийомів, що сприяють одержанню надранньої продукції картоплі у весняні та літні строки й підвищенню її урожайності. За рахунок яровізації досягається скорочення вегетаційного періоду рослин, підвищується енергія та інтенсивність процесів росту і розвитку. Лисенко Т. Д. [21, с. 9] відзначив, що під час яровізації на бульбах картоплі добре розвиваються не лише верхівкові, а й більшість бічних вічок. В місцях росту вічок, ще до висаджування, проходять якісні (стадійні) зміни клітин, завдяки чому рослини прискорено вступають у фазу цвітіння і бульбоутворення. Навколо ростків під час яровізації з'являються напливи, щільно вкриті горбками зачаткових корінців, які через 3-5 діб після висаджування у грунт формують потужну кореневу систему, через яку рослини отримують поживні речовини 3 грунту. Яровізація сприяє прискоренню появи сходів на 4-11 діб, цвітіння - на 7-14 діб, врожаю ранньої продукції - на 12-15 діб раніше, ніж за висаджування не яровізованим посадковим матеріалом. 3 таблиці 1 видно, що яровізація насіннєвого матеріалу у всіх випадках забезпечує підвищення врожаю бульб. Ефект від яровізації обумовлений біологічними вимогами рослин картоплі до факторів росту і розвитку і їх взаємодії з зовнішнім середовищем. Крім того, у ряді районів, де картопля уражується фітофторою при висаджуванні яровізованими бульбами ранніх сортів вдається зібрати урожай до строку масового розповсюдження хвороби.

Важливе значення для одержання раннього врожаю картоплі мають способи передсадивної підготовки бульб. Завдяки їх застосуванню прискорюється проходження фенологічних фаз росту та розвитку і зростає продуктивність рослин. Встановлено залежність формування урожаю картоплі молодої (на прикладі сорту Імпала) від підготовки садивного матеріалу до висаджування. За різних передсадивних обробок бульб (водою, ацетиленом, киснем та розчином сечовини) стабільно найбільш ефективним способом, передсадивної підготовки, $є$ обробка бульб під час висаджування розчином сечовини 20 кг/т. Спосіб забезпечує кращий ріст, розвиток та урожайність картоплі. Приріст урожайності, в середньому, складає 4,4 т/га - рис. 5. 
Таблиця 1

Вплив яровізації (пророщування) на урожайність ранньої картоплі в зоні північного Степу України (середнє за 2008-2010 рр.).

\begin{tabular}{|l|c|c|c|c|c|c|}
\hline \multirow{3}{*}{ Сорт } & \multicolumn{5}{|c|}{ Урожайність, т/га } \\
\cline { 2 - 7 } & \multicolumn{3}{|c|}{$\begin{array}{c}\text { непророщені } \\
\text { (без яровізації), }\end{array}$} & \multicolumn{2}{c|}{$\begin{array}{c}\text { пророщені (яровізовані), } \\
\text { доба від садіння }\end{array}$} \\
\cline { 2 - 7 } & $\mathbf{5 0 - т а ~}$ & $\mathbf{6 0 - т а}$ & $\mathbf{7 0 - т a}$ & $\mathbf{5 0 - т а ~}$ & $\mathbf{6 0 - т а}$ & $\mathbf{7 0 - т а}$ \\
\hline Імпала & 16,4 & 21,4 & 29,8 & 13,1 & 17,9 & 24,4 \\
\hline Веста & 16,0 & 21,8 & 28,4 & 12,6 & 18,0 & 23,2 \\
\hline Божедар & 12,3 & 15,5 & 18,9 & 10,8 & 13,5 & 15,6 \\
\hline Косень, 95 & 6,1 & 9,4 & 15,2 & 5,0 & 8,2 & 10,2 \\
\hline Поран & 17,2 & 19,5 & 23,4 & 11,0 & 13,9 & 16,0 \\
\hline Серпанок & 12,4 & 13,8 & 16,1 & 9,6 & 11,0 & 15,4 \\
\hline Радич & 12,0 & 13,8 & 17,2 & 9,8 & 11,9 & 15,8 \\
\hline Жеран & 14,0 & 16,2 & 18,0 & 10,2 & 13,1 & 16,7 \\
\hline
\end{tabular}

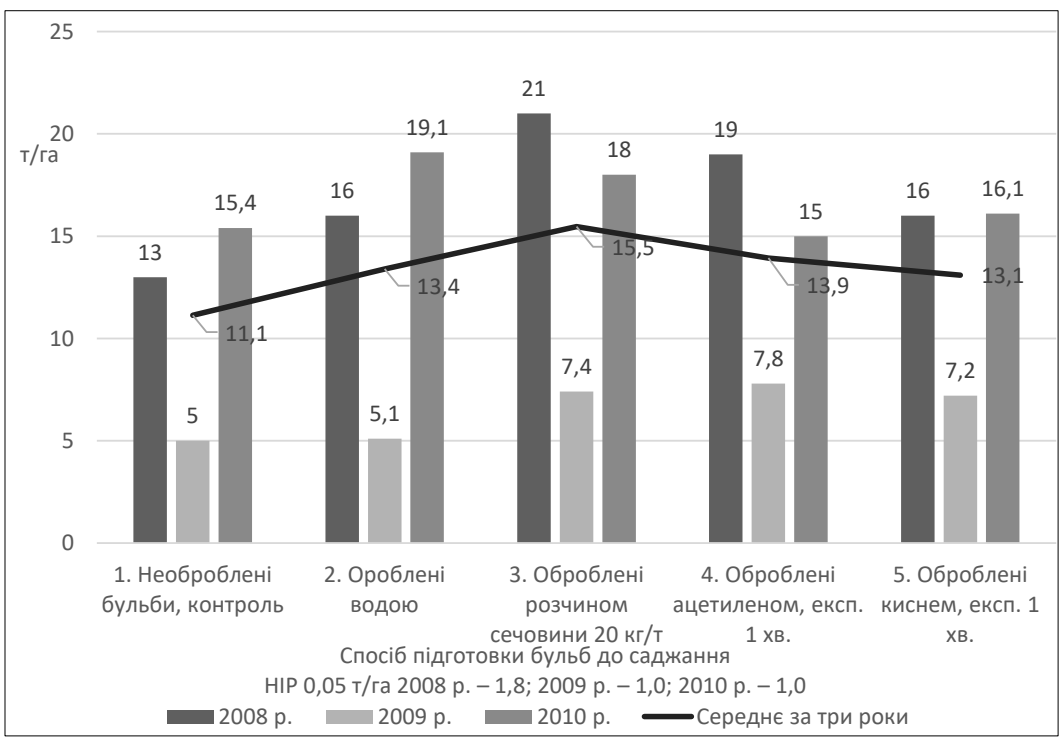

Рис. 5. Формування раннього урожаю картоплі сорту Імпала, т/га залежно від способів передсадивної обробки бульб за 2008-2010 рр. 


\section{4. Способи удобрення картоплі ранньої за весняного строку висаджування в умовах північного Степу України на зрошенні}

Добрива сприяють змінам в рослинах картоплі в процесі їх росту та розвитку, що в кінцевому результаті відображається на врожаї бульб. Ефективність застосування мінеральних добрив залежить від правильного співвідношення азоту, фосфору, калію та способу їх внесення. При визначенні найбільш ефективних доз мінеральних добрив слід враховувати окрім стану грунту ще й економічний бік питання.

Внесення мінеральних добрив у різних поєднаннях NPK (за винятком $\mathrm{N}_{30} \mathrm{P}_{30} \mathrm{~K}_{15} 3$ фертигацією) забезпечує суттєвий приріст урожайності бульб (від 14 до 32 \% та більше). В зоні північного Степу України найвищий приріст урожаю забезпечує внесення $\mathrm{N}_{60} \mathrm{P}_{60} \mathrm{~K}_{30}$ врозкид восени та $\mathrm{N}_{60} \mathrm{P}_{60} \mathrm{~K}_{30}$ локально при садінні. Перевагою локального внесення $є$ зниження норми використання туків вдвічі, за рахунок чого скорочуються витрати та екологічне навантаження на грунт - рис. 6. [22. с. 78].

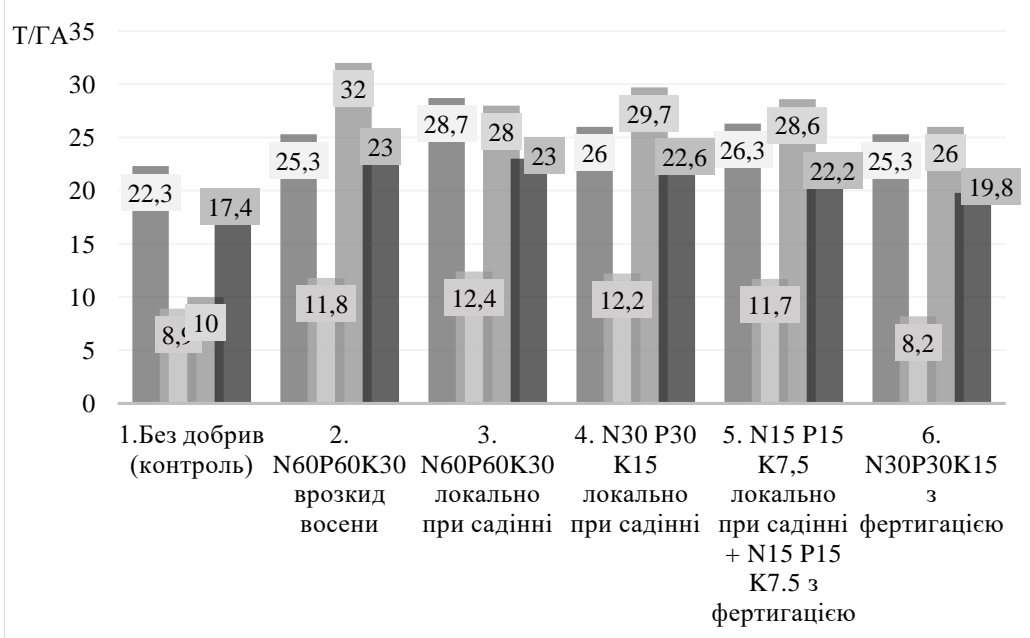

СПОСІБ ТА ДОЗА ВНЕСЕННЯ ДОБРИВ

HIP 0,05 Т/ГА 2008 P. - 0,79; 2009 P. - 1,0; 2010 P. - 1,2

$\square 2008$ p. $\quad 2009$ p. $\quad 2010$ p. $\square$ Середне за три роки

Рис. 6. Формування раннього врожаю картоплі сорту

Імпала, т/га залежно від доз мінеральних добрив

3а 2008-2010 pp. 
Пророщені (яровізовані) впродовж 20 діб при $\mathrm{t} 12-16{ }^{\circ} \mathrm{C}$ та вологості повітря 75-80 \% НВ бульби оброблені розчином сечовини (20 кг/т) слід висаджувати за локального внесення мінеральних добрив $\left(\mathrm{N}_{60} \mathrm{P}_{60} \mathrm{~K}_{30}\right)$, за даного способу виробництва урожайність зростає на $40 \%$ та більше. Для конвеєрного забезпечення ринку молоду картоплю збирати на 50-ту, 60-ту та 70-ту добу від садіння.

Урожайність і товарність молодих бульб картоплі (на прикладі сорту Імпала та Загадка), зростає на 70-ту добу від висаджування (третя копка), що пояснюється збільшенням маси бульб в урожаї, та одночасно їх товарності - рис. 7-10.

Урожайність ранньої (молодої) картоплі сорту Імпала в динамічних підкопуваннях

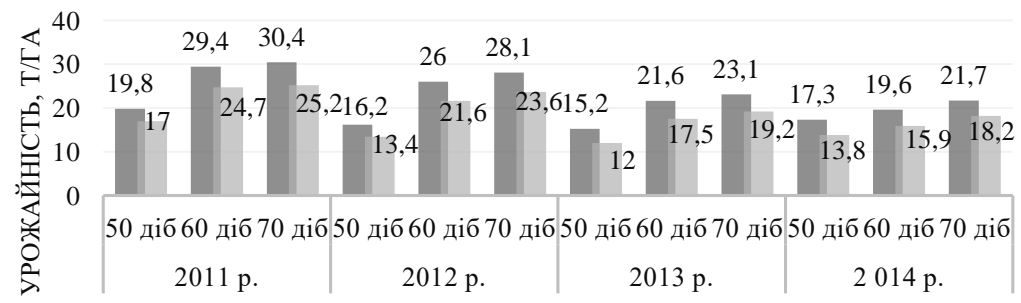

ДАТА ПІДКОПУВАННЯ

ш Загальна Товарних бульб

\section{Рис. 7. Формування раннього урожаю картоплі сорту Імпала} весняного строку висаджування

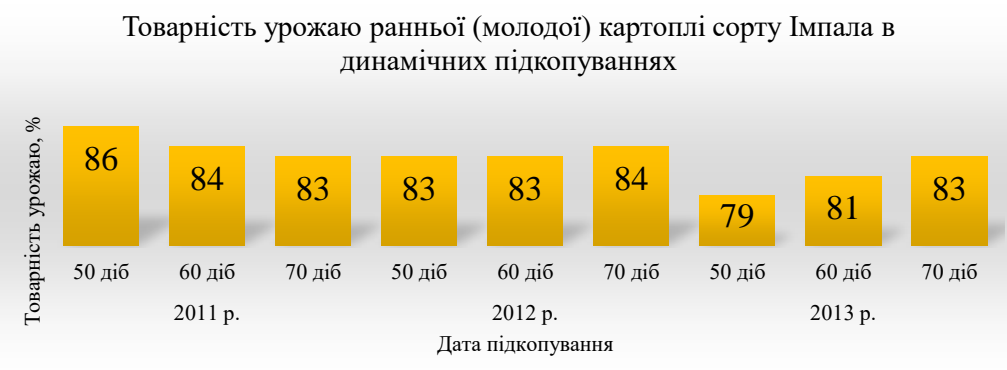

Рис. 8. Товарність раннього урожаю картоплі сорту Імпала весняного строку висаджування 


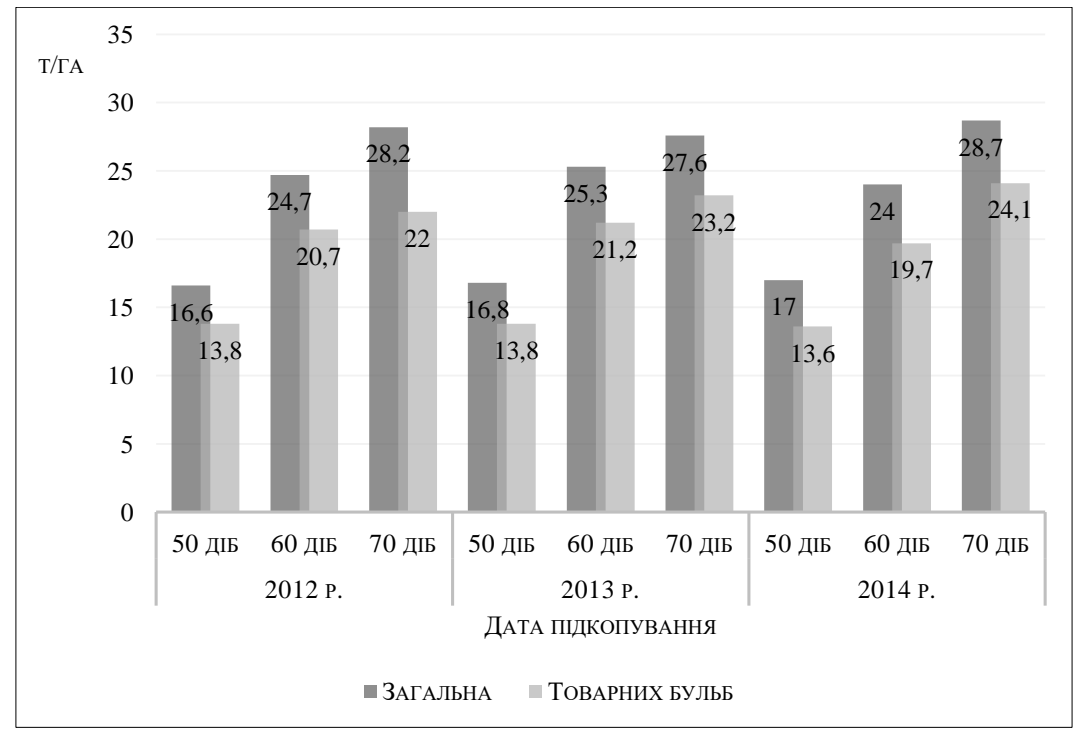

Рис. 9. Формування раннього урожаю картоплі сорту Загадка весняного строку висаджування

$\%$

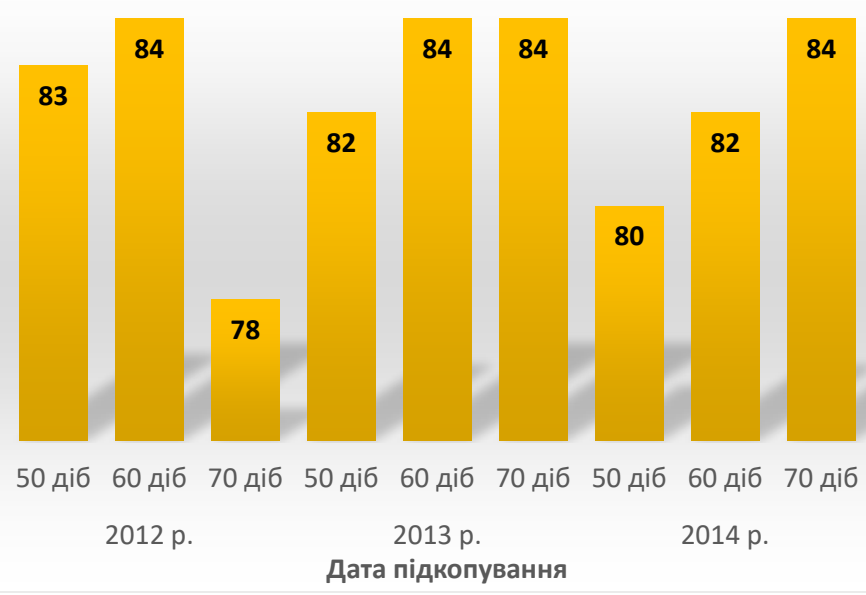

Рис. 10. Товарність раннього урожаю картоплі сорту Загадка весняного строку висаджування 
За першого підкопування картоплі молодої (на прикладі сорту Імпала) за структорою урожай поділяється наступним чином: значну частину урожаю становлять середньо-дрібні (26-50 г) та дрібні бульби (<25 г), в середньому, - 72,2\% та $18 \%$ відповідно. $18 \%$ припадає на середні бульби (51-80 г) та 1,7 \% на великі (> 80 г). До третьої копки зростає відсоток середніх та великих бульб, порівняно з першою копкою на 56,7 \% та 10,1 \% відповідно, одночасно зменшується кількість середньо-дрібних та дрібних бульб (таблиця 2).

Таблиця 2

Структура раннього урожаю картоплі молодої сорту Імпала весняного строку висаджування

\begin{tabular}{|c|c|c|c|c|c|}
\hline \multirow{2}{*}{\multicolumn{2}{|c|}{$\begin{array}{c}\text { Доба від } \\
\text { садіння до } \\
\text { підкопування }\end{array}$}} & \multicolumn{4}{|c|}{ Структура урожаю бульб, т/га } \\
\hline & & \multirow{2}{*}{$\begin{array}{c}\begin{array}{c}\text { Великі } \\
>\mathbf{8 0} \text { г }\end{array} \\
0,2\end{array}$} & \multirow{2}{*}{$\begin{array}{c}\text { Середні } \\
\mathbf{5 1 - 8 0} \text { г } \\
1,5\end{array}$} & \multirow{2}{*}{$\begin{array}{c}\text { Середньо- } \\
\text { дрібні } \\
\mathbf{2 6 - 5 0} \text { г } \\
15,3 \\
\end{array}$} & \multirow{2}{*}{$\begin{array}{c}\begin{array}{c}\text { Дрібні } \\
<25 \text { г }\end{array} \\
2,8\end{array}$} \\
\hline$\dot{2}$ & 50-та & & & & \\
\hline$\stackrel{ت}{\overparen{\sigma}}$ & 60-та & 2,6 & 17,8 & 4,3 & 4,7 \\
\hline ก & 70-та & 2,4 & 15,6 & 7,2 & 5,2 \\
\hline \multirow{3}{*}{$\stackrel{\stackrel{\dot{2}}{N}}{\stackrel{\sim}{0}}$} & 50-та & 0,4 & 1,3 & 11,7 & 2,8 \\
\hline & 60-та & 2,1 & 15,2 & 4,3 & 4,4 \\
\hline & 70-та & 3,3 & 17,6 & 2,7 & 4,5 \\
\hline \multirow{3}{*}{ 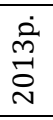 } & 50-та & 0,1 & 2,5 & 9,4 & 3,2 \\
\hline & 60-та & 2,4 & 9,3 & 5,8 & 4,1 \\
\hline & 70-та & 3,2 & 12,7 & 3,3 & 3,9 \\
\hline \multirow{3}{*}{$\begin{array}{l}\dot{2} \\
\stackrel{+}{\sigma} \\
\stackrel{2}{N}\end{array}$} & 50-та & 0,3 & 1,4 & 12,1 & 3,5 \\
\hline & 60-та & 2,5 & 10,3 & 3,1 & 3,7 \\
\hline & 70-та & 2,7 & 13,6 & 1,9 & 3,5 \\
\hline
\end{tabular}

\section{5. Технологія вирощування картоплі ранньої (молодої)} літнього строку висаджування у двоурожайній культурі в зоні північного Степу України для літньо - осіннього споживання на зрошенні

Значну роль в одержанні ранньої продукції картоплі у двоурожайній культурі займає підготовка свіжозібраних бульб до висаджування. Складність виробництва даним способом полягає у сортових особливостях (придатність до двоурожайної культури); зокрема в недружності сходів [23, с. 48].

Бруньки на свіжозібраних бульбах не проростають через те, що в таких бульбах немає поживних розчинних речовин для них. Якщо 
забезпечити відтік розчинних поживних речовин до бруньок бульб то вони у любий час року пробуджуються і починають рости. В недозрілих бульбах чимало розчинних поживних речовин (моноцукри, амінокислоти) проте бруньки бульб не можуть їх використовувати через те, що ці речовини (крохмаль, запасні білки, та інші) переходять знову в розчинні - цукри та амінокислоти. Посилити дихання свіжозібраних бульб для прискорення проходження періоду спокою можна і не ушкоджуючи шкірочку. Для цього бульби слід збирати не чекаючи повного їх дозрівання (шкірочка легко здирається від тертя). Крім того, для літнього садіння свіжозібраними бульбами важливо збирати посадковий матеріал, коли бульби багаті матеріалом для дихання - редукуючими цукрами. Підвищення вмісту редукуючих цукрів у бульбах досягається передзбиральним поливом. Редукуючі цукри в недозрілих бульбах картоплі зазвичай перетворюються на крохмаль, або ж використовуються рослиною для утворення щільної шкірочки, за умови температури зовнішнього середовища не вище $25^{\circ} \mathrm{C}$. Коли недозрілі бульби саджають у грунт 3 температурами повітря $30^{\circ} \mathrm{C}$ редукуючі цукри в бульбах майже повністю використовуються на дихання, оскільки крохмаль за таких температур майже не утворюється. Такий спосіб посилення дихання бульб викликає розпад крохмалю та запасних білків і перехід їх в розчинні поживні речовини, необхідні для росту, і тому бульби швидко проходять період спокою. Крім доступу кисню до бульб та високих температур посиленню дихання необхідна достатня вологість навколишнього середовища. Отже, створивши умови, за яких достатній доступ повітря, температура та вологість навколишнього середовища, сильно прискорюється проходження бульбами картоплі періоду спокою. За таких умов активність дихання бульб картоплі зростає у 3-4 рази порівняно з активністю дихання бульб, що знаходяться у звичайних умовах. Довжина періоду спокою бульб скорочується з 3-4 місяців до 1 місяця. Скорочення періоду спокою свіжозібраних бульб дозволяє проводити літнє садіння картоплі недозрілими бульбами. Таким чином, регулювання періоду спокою бульб картоплі шляхом зміни умов зовнішнього середовища має велике практичне значення.

При виробництві картоплі молодої часто використовують літні посадки бульбами урожаю минулого року - рис.11. Проте висаджування минулорічних бульб застосовують лише дрібні товаровиробники, оскільки це вимагає значних витрат робочої сили, спеціальних приміщень та техніки. Тому вченими зроблено спроби замінити дані трудомісткі процеси на більш досконалі та прості - за 
рахунок використання речовин, що стимулюють ріст рослин. Обробка бульб розчинами мінеральних добрив та хімічних сполук $\epsilon$ додатковим джерелом поживних речовин у початковий період росту рослин. Одночасно даний прийом стимулює перехід запасних поживних речовин бульб в засвоювані форми. Використання хімічних стимуляторів росту для порушення періоду спокою бульб дозволяє використовувати свіжозібрані бульби для висаджування.

Важливе значення в одержанні ранньої продукції картоплі у двоурожайній культурі має спосіб підготовки свіжозібраних бульб до висаджування - пророщування (яровізація) та вплив різних поєднань ростових речовин.

Зважаючи на те, що в «Переліку пестицидів і агрохімікатів, дозволених до використання в Україні» зареєстрована значна кількість речовин, використання яких при обробці свіжозібраних бульб не менш ефективне за загальноприйнятий чотирикомпонентний розчин для пробудження свіжозібраних бульб і в 3-4 рази дешевше, завдяки чому знижується собівартість виробництва і зростають прибутки, можна використовувати й інші поєднання ростових речовин - рис. 12.

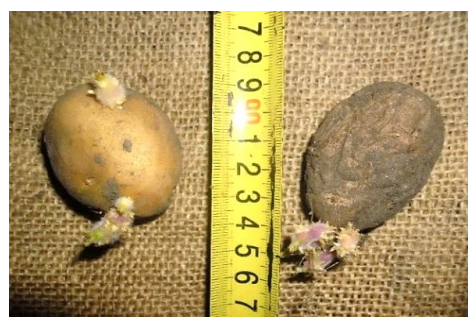

Рис. 11. Бульби сорту Імпала (зліва свіжозібрані пророщені, справа - минулорічні, що зберігались в умовах складського приміщення) ориг.

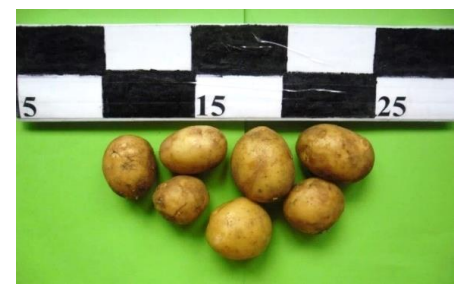

Рис. 12. Бульби сорту Імпала свіжозібрані непророщені (ориг.) 
Прискорення настання основних фенологічних фаз росту i розвитку рослин картоплі (на прикладі сорту Імпала) визначається пророщуванням (яровізацією) свіжозібраних бульб та впливом різних поєднань ростових речовин (табл. 3-4).

Таблиця 3

Кількість стебел у рослин картоплі сорту Імпала залежно від впливу ростових речовин, шт./кущ

\begin{tabular}{|c|c|c|c|c|c|c|c|c|}
\hline \multirow[b]{2}{*}{$\begin{array}{c}\text { Спосіб підготовки бульб різного } \\
\text { походження до висаджування }\end{array}$} & \multicolumn{4}{|c|}{ Пророщені } & \multicolumn{4}{|c|}{ Непророщені } \\
\hline & 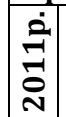 & 文 & 官 & 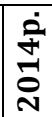 & 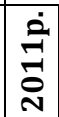 & ปิ่ & 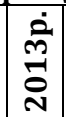 & 守 \\
\hline 1. Минулорічні бульби & 4,7 & 4,0 & 5,3 & 4,3 & & & & \\
\hline \multicolumn{9}{|l|}{ Свіжозібрані бульби: } \\
\hline $\begin{array}{l}\text { 2. Чотирикомпонентний розчин } \\
\text { (контроль) }\end{array}$ & 2,9 & 3,3 & 3,7 & 3,6 & 3,0 & 3,0 & 3,8 & 3,5 \\
\hline 3. Обробка водою (абсолютний контроль) & - & 3,3 & 3,0 & - & - & 4,0 & 2,0 & - \\
\hline $4.2 \%$ Біоглобін & - & 3,3 & - & - & - & 3,4 & - & - \\
\hline 5. Фумар $(0,02 \%)+$ гіберелін $(0,0005 \%)$ & 3,4 & 4,0 & 4,23 & 3,9 & 4,0 & 4,2 & 4,1 & 4,0 \\
\hline 6. Реастим (5 \%) + гіберелін $(0,0005 \%)$ & 3,3 & 3,0 & 4,6 & 4,4 & 3,9 & 3,3 & 4,7 & 4,2 \\
\hline $\begin{array}{l}\text { 7. Гумат калію }(0,5 \%)+\text { гіберелін } \\
(0,0005 \%)\end{array}$ & 2,9 & - & 3,63 & 3,2 & 3,7 & - & 3,6 & 3,0 \\
\hline Середнє по досліду & 3,5 & 3,5 & 4,03 & 3,9 & 3,6 & 3,5 & 3,7 & 3,7 \\
\hline $\mathrm{HIP}_{0,05, \text { шт./кущ }}$ & 1,4 & 1,3 & 1,3 & 1,2 & 1,2 & 1,3 & 1,1 & 1,1 \\
\hline
\end{tabular}

Примітки: Сорт нестабільно реагує на обробку: водою, Біоглобіном, Гуматом калію.

Таблиця 4

Кількість стебел у рослин картоплі сорту Загадка залежно від впливу ростових речовин, шт./кущ

\begin{tabular}{|c|c|c|c|c|c|c|}
\hline \multirow[b]{2}{*}{$\begin{array}{c}\text { Спосіб підготовки бульб } \\
\text { до висаджування }\end{array}$} & \multicolumn{3}{|c|}{ Пророщені } & \multicolumn{3}{|c|}{ Непророщені } \\
\hline & 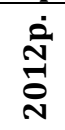 & in & 客 & 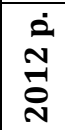 & 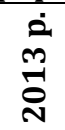 & $\underset{⿱ 亠 乂}{\stackrel{d}{2}}$ \\
\hline \multicolumn{7}{|c|}{ Свіжозібрані бульби: } \\
\hline 1. Чотирикомпонег & 1,1 & 2,0 & 4,0 & 1,0 & 1,9 & 3,9 \\
\hline 2. Обробка во & 1,1 & - & - & 1,0 & - & - \\
\hline 3. 0,3\% Пот & 1,6 & $\begin{array}{llll}- & \\
\end{array}$ & - & 1,4 & - & - \\
\hline 4.2 \% Біоглобін & 1,5 & 2,2 & 4,1 & 1,4 & 2,3 & 4,1 \\
\hline 5. Реастим (5 \%) + гіберелін $(0,0005 \%)$ & 1,7 & 2,1 & 4,6 & 1,6 & 2,0 & 4,5 \\
\hline Середнє по досліду & 1,4 & 1,9 & 4,2 & 1,2 & 2,0 & 4,2 \\
\hline HIP $_{0,05, \text { шт./кущ }}$ & 0,9 & 0,9 & 0,9 & 0,5 & 1,6 & 0,9 \\
\hline
\end{tabular}

Примітки: сорт нестабільно реагує на обробки: водою, Потейтіном. 
Пророщування свіжозібраних бульб для висаджування у двоурожайній культурі впливає на інтенсивність проростання бульб, проте вирішальною $є$ обробка різними поєднаннями ростових речовин. Найбільш інтенсивне проростання свіжозібраних бульб - при використанні водних розчинів Реастиму з гібереліном та Фумару з гібереліном.

\section{6. Стебла, листки та фоотосинтез картоплі ранньої у двоурожайній культурі}

Важливим показником продуктивності картоплі $€$ стеблоутворююча здатність бульб. До факторів, що впливають на стеблеутворюючу здатність відносяться: розмір бульб та їх передсадивна підготовка. Рослини з бульб, оброблених стимуляторами росту, дуже чутливі до нестачі вологи і лише за вирощування на зрошенні здатні повністю реалізувати свої можливості по формуванню врожаю. За умов зрошення ефективність передсадивної обробки бульб стимуляторами росту проявляється сильніше. Тому у рослин, сформованих $з$ минулорічних бульб, відмічається на 1,2-1,7 стебел на кущ більше. Формування стебел у кущі залежить від способу підготовки бульб до висаджування, а саме - застосування різних поєднань хімічних речовин та стимуляторів росту. Найкращі показники, на прикладі сорту Імпала, (за обробки свіжозібраних бульб розчином Реастим + гіберелін, для сорту Загадка - (біоглобін та Реастим + гіберелін), як $з$ пророщених так і з непророщених свіжозібраних бульб - табл. 3-4. Встановлено тісні кореляційні зв'язки між кількістю стебел та урожайністю бульб досліджуваних сортів: $\mathrm{r}=0,95$ (пророщені), $r=0,96$ (непророщені) сорт Імпала та $r=0,99$ (пророщені та непророщені) - сорт Загадка, що вказує на зростання урожаю бульб зі збільшенням кількості стебел у кущі - рис. 13-16.

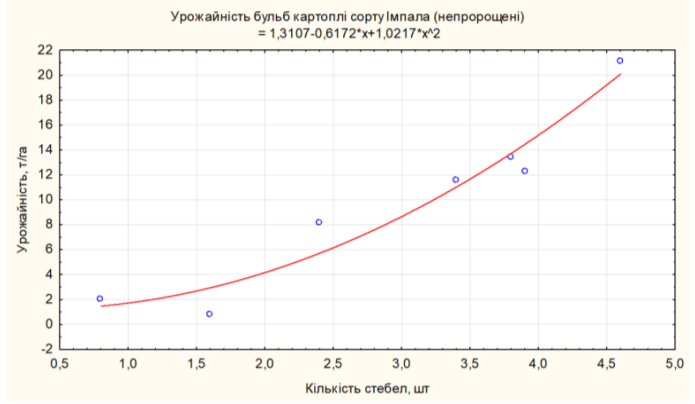

Рис. 13. Кількість стебел, шт: урожайність, т/га: $\mathrm{y}=-4,2711+4,8438 \cdot x ; r=0,9487$ 


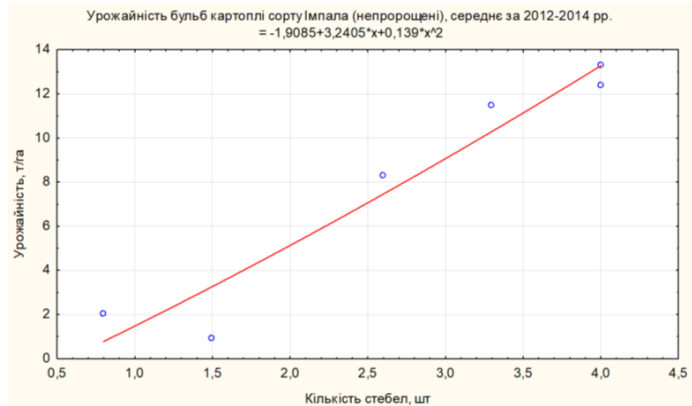

Рис 14. Кількість стебел, шт: Урожайність, т/га: $y=-2,5484+3,9284 \cdot x ; r=0,9650$

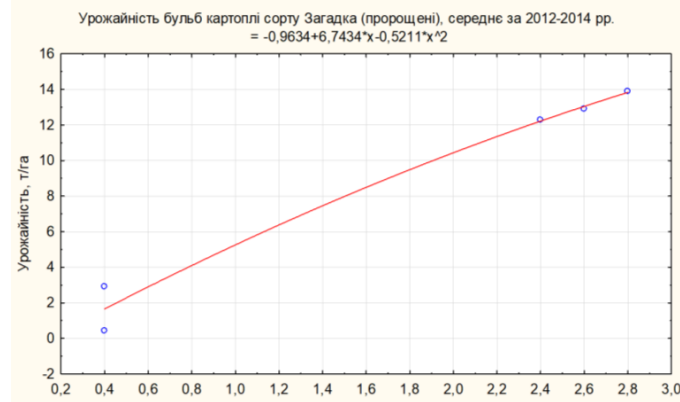

Рис. 15. Кількість стебел, шт: Урожайність, т/га: $y=-0,3923+5,1583 \cdot x ; r=0,9898$

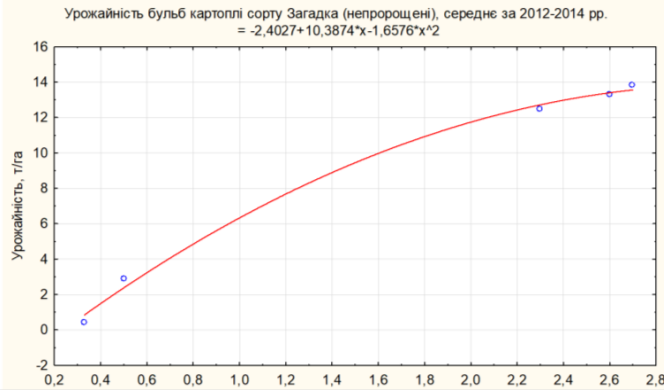

Рис. 16. Кількість стебел, шт: Урожайність, т/га: $y=-0,5916+5,4399 \cdot x ; r=0,9947$ 
Кількість стебел та їх висота визначають площу асиміляційної поверхні, що в свою чергу впливає на урожайність рослин (на прикладі сортів картоплі Імпала та Загадка) - рис. 17-18.

Площа листкової поверхні рослинами сортів Імпала та Загадка формується залежно від сортової реакції на розчини, якими обробляли бульби перед висаджуванням.

Сорт Імпала реагує на обробку водними розчинами Фумару 3 гібереліном та Реастиму 3 гібереліном. Встановлено тісні кореляційні зв'язоки між площею листків та урожайністю бульб $\mathrm{r}=0,94 ; \mathrm{y}=-4,07+1,12 \cdot \mathrm{x} \quad$ (пророщені), $\mathrm{r}=0,98 ; \mathrm{y}=-2,80+0,93 \cdot \mathrm{x}$ (непророщені), що вказує на зростання урожаю бульб у варіантах, де збільшувалась площа листків. Сорт Загадка реагує на обробку розчинами Біоглобіну та Реастиму. Збільшення площі листків тісно пов'язано зі зростанням урожаю, про що свідчить тісний кореляційний зв'язок: $\mathrm{r}=0,98 ; \mathrm{y}=2,80+0,93 \cdot \mathrm{x}$ (пророщені), $\mathrm{r}=0,99$; $\mathrm{y}=2,54+1,0 \cdot \mathrm{x}$ (непророщені).

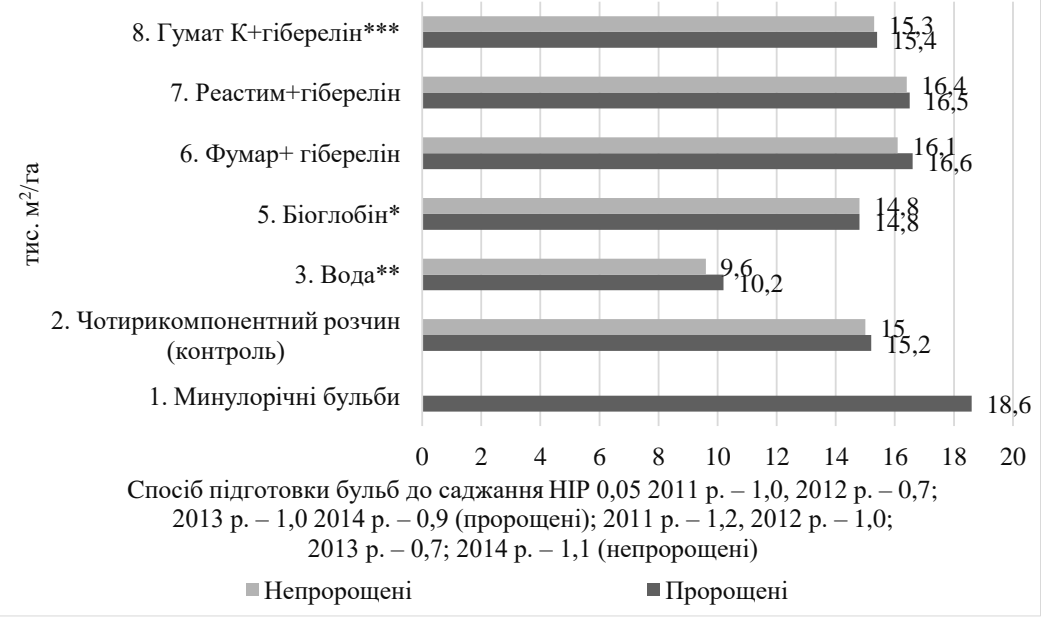

Примітка. * - однорічні, ${ }^{* *}$ - дворічні, ${ }^{* * *}$ - трирічні дані.

Рис. 17. Формування площі листкової поверхні картоплі сорту Імпала залежно від впливу ростових речовин (фаза цвітіння)

Основним показником ефективності різних способів підготовки свіжозібраних бульб до висаджування є підвищення або зниження урожайності. 
Сорт Імпала стабільно позитивно реагує на обробку свіжозібраних бульб перед садінням водними розчинами Фумару з гібереліном та Реастиму з гібереліном (пророщені та непророщені) - таблиця 5.

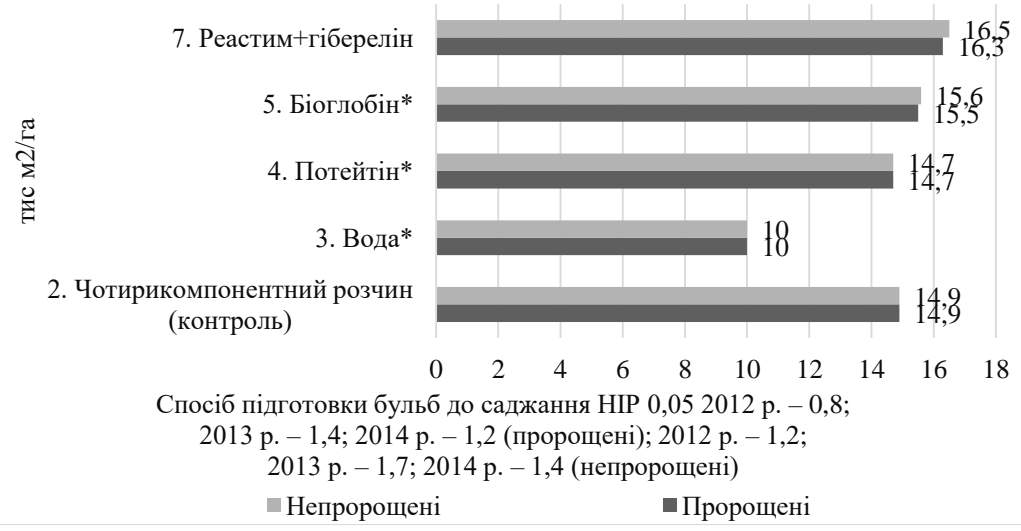

Примітка. * - однорічні дані.

Рис. 18 Формування площі листкової поверхні картоплі сорту Загадка залежно від впливу ростових речовин (фаза цвітіння).

\section{7. Урожайність картоплі літнього строку вирощування у двоурожайній культурі}

Висаджування минулорічних бульб (21,1 т/га) значно перевищує за урожайністю висаджування свіжозібраними. Це пояснюється фізіологічним станом та біохімічним складом бульб різного походження [24, с. 232]. За вдало підібраними варіантами розчинів для пробудження свіжозібраних бульб перед садінням вища і товарність бульб і їх урожайність (на прикладі сортів Імпала та Загадка).

Товарність бульб сорту Імпала за використання розчинів Фумару 3 гібереліном та Реастиму з гібереліном суттєво перевищувала показники контролю та інших варіантів. В середньому, за роки досліджень, урожайність товарних бульб на контролі склала 11,6 т/га (пророщені) та 11,4 т/га (непророщені), що на 0,7 т/га (пророщені) та на 0,9 т/га (непророщені), Фумар з гібереліном та на 1,8 т/га (пророщені), 1,9 т/га (непророщені) перевищує показники контролю (Реастим 3 гібереліном). За іншими варіантами досліджень прибавки урожаю, порівняно 3 контролем не встановлено. Слід зазначити, що урожай з минулорічних бульб 
(варіант 1), в середньому за чотири роки, нижчий на 3-4\% порівняно з варіантами 6 та 7 - таблиця 5-6.

Таблиця 5

\section{Урожайність товарних бульб картоплі сорту Імпала, т/га}

\begin{tabular}{|c|c|c|c|c|c|c|c|c|}
\hline \multirow[b]{2}{*}{$\begin{array}{c}\text { Спосіб підготовки } \\
\text { бульб різного } \\
\text { походження до } \\
\text { висаджування }\end{array}$} & \multicolumn{4}{|c|}{ Пророщені } & \multicolumn{4}{|c|}{ Непророщені } \\
\hline & $\stackrel{\dot{2}}{\stackrel{1}{2}}$ & 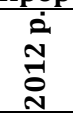 & $\stackrel{\dot{a}}{\stackrel{2}{2}}$ & 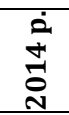 & $\stackrel{\dot{2}}{\stackrel{\text { N }}{\sigma}}$ & $\frac{\mathfrak{d}}{\mathfrak{2}}$ & $\stackrel{\dot{n}}{m}$ & $\frac{2}{\dot{2}}$ \\
\hline 1. Минулорічні бульби & 15,1 & 25,1 & 26,3 & 18,1 & & & & \\
\hline \multicolumn{9}{|c|}{ Свіжозібрані бульби: } \\
\hline $\begin{array}{l}\text { 2. Чотирикомпонент- } \\
\text { ний розчин (контроль) }\end{array}$ & 7,5 & 12,0 & 14,7 & 12,4 & 7,6 & 10,9 & 15,1 & 12,1 \\
\hline $\begin{array}{l}\text { 3. Обробка водою } \\
\text { (абсолютний контроль) }\end{array}$ & - & 2,1 & 1,0 & - & - & 2,3 & 1,2 & - \\
\hline 4. 2 \% Біоглобін & - & 8,2 & - & - & - & 8,2 & - & - \\
\hline $\begin{array}{l}\text { 5. Фумар }(0,02 \%)+ \\
\text { гіберелін }(0,0005 \%)\end{array}$ & 8,4 & 10,4 & 15,3 & 15,2 & 8,0 & 10,8 & 15,3 & 15,4 \\
\hline $\begin{array}{l}\text { 6. Реастим }(5 \%)+ \\
\text { гіберелін }(0,0005 \%)\end{array}$ & 7,9 & 14,1 & 15,8 & 15,9 & 7,8 & 13,6 & 16,0 & 15,7 \\
\hline $\begin{array}{l}\text { 7. Гумат калію }(0,5 \text { \%) + } \\
\text { гіберелін }(0,0005 \%)\end{array}$ & 7,7 & - & 12,2 & 13,0 & 7,3 & - & 13,1 & 12,8 \\
\hline Середнє по досліду & 9,3 & 11,8 & 14,1 & 15,3 & 7,9 & 9,1 & 12,2 & 14,1 \\
\hline 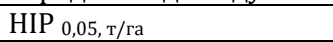 & 1,3 & 1,1 & 0,9 & 1,0 & 1,3 & 0,9 & 1,0 & 1,3 \\
\hline
\end{tabular}

Примітки: сорт нестабільно реагує на обробку: водою, Біоглобіном, Гуматом Калію

Таблиця 6

Товарність картоплі молодої сорту Імпала, \%

\begin{tabular}{|c|c|c|c|c|c|c|c|c|}
\hline \multirow[b]{2}{*}{$\begin{array}{c}\text { Спосіб підготовки бульб } \\
\text { різного походження до } \\
\text { висаджування }\end{array}$} & \multicolumn{4}{|c|}{ Пророщені } & \multicolumn{4}{|c|}{ Непророщені } \\
\hline & 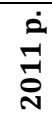 & 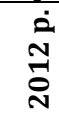 & $\stackrel{\dot{a}}{m}$ & $\stackrel{\dot{2}}{\grave{d}}$ & $\stackrel{\dot{2}}{\stackrel{2}{2}}$ & 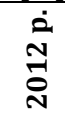 & 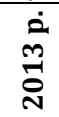 & 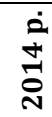 \\
\hline 1 & 2 & 3 & 4 & 5 & 6 & 7 & 8 & 9 \\
\hline 1. Минулорічні бульби & 70 & 71 & 80 & 76 & & & & \\
\hline \multicolumn{9}{|l|}{ Свіжозібрані бульби: } \\
\hline $\begin{array}{l}\text { 2. Чотирикомпонентний } \\
\text { розчин (контроль) }\end{array}$ & 73 & 73 & 81 & 79 & 73 & 73 & 80 & 79 \\
\hline $\begin{array}{l}\text { 3. Обробка водою } \\
\text { (абсолютний контроль). }\end{array}$ & - & 73 & 64 & - & - & 79 & 60 & - \\
\hline $4.2 \%$ Біоглобін & - & 74 & - & - & $\begin{array}{ll}- \\
\end{array}$ & 74 & - & $\begin{array}{ll}- \\
\end{array}$ \\
\hline $\begin{array}{l}\text { 5. Фумар }(0,02 \%)+ \\
\text { гіберелін }(0,0005 \%)\end{array}$ & 73 & 73 & 83 & 81 & 74 & 74 & 83 & 82 \\
\hline
\end{tabular}


Закінчення таблиці 6

\begin{tabular}{|l|c|c|c|c|c|c|c|c|}
\hline \multicolumn{1}{|c|}{1} & 2 & 3 & 4 & 5 & 6 & 7 & 8 & 9 \\
\hline $\begin{array}{l}\text { 6. Реастим (5 \%) + гіберелін } \\
\text { (0,0005\%). }\end{array}$ & 74 & 74 & 82 & 84 & 74 & 74 & 83 & 83 \\
\hline $\begin{array}{l}\text { 7. Гумат калію (0,5\%)+ } \\
\text { гіберелін (0,0005\%) }\end{array}$ & 74 & - & 75 & 80 & 73 & - & 74 & 80 \\
\hline Середнє по досліду & 73 & 73 & 77 & 79 & 74 & 75 & 75 & 81 \\
\hline HІР $0,05, \%$ & 2,7 & 2,0 & 3,3 & 2,1 & 3,5 & 2,4 & 3,7 & 2,4 \\
\hline
\end{tabular}

Примітки: сорт нестабільно реагує на обробку: водою, Біоглобіном, Гуматом калію.

Сорт Загадка позитивно реагує на обробку бульб перед садінням водними розчинами Біоглобіну та Реастиму 3 гібереліном, відповідно зростає урожайність і товарність бульб (таблиця 8-9).

Таблиця 8

Урожайність товарних бульб картоплі сорту Загадка, т/га

\begin{tabular}{|c|c|c|c|c|c|c|}
\hline \multirow[b]{2}{*}{$\begin{array}{c}\text { Спосіб підготовки бульб до } \\
\text { висаджування }\end{array}$} & \multicolumn{3}{|c|}{ Пророщені } & \multicolumn{3}{|c|}{ Непророщені } \\
\hline & 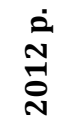 & $\underset{\stackrel{m}{m}}{\stackrel{\dot{m}}{\rho}}$ & $\begin{array}{l}\dot{a} \\
\dot{d} \\
\dot{S}\end{array}$ & 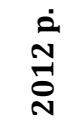 & 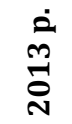 & $\begin{array}{l}\dot{d} \\
\dot{d} \\
\dot{S}\end{array}$ \\
\hline \multicolumn{7}{|c|}{ Свіжозібрані бульби: } \\
\hline $\begin{array}{l}\text { 1. Чотирикомпонентний розчин } \\
\text { (контроль)* }\end{array}$ & 8,9 & 14,1 & 13,9 & 8,8 & 14,9 & 13,7 \\
\hline $\begin{array}{l}\text { 2. Обробка водою (абсолютний } \\
\text { контроль) }\end{array}$ & 1,3 & - & - & 1,1 & - & - \\
\hline 3. 0,3\% Потейтін & 8,8 & - & - & 8,7 & - & - \\
\hline $4.2 \%$ Біоглобін & 9,8 & 14,3 & 14,5 & 9,7 & 15,0 & 15,2 \\
\hline $\begin{array}{l}\text { 5. Реастим (5 \%) + гіберелін } \\
(0,0005 \%)\end{array}$ & 11,0 & 15,3 & 15,5 & 11,1 & 15,0 & 15,3 \\
\hline Середнє по досліду & 8,0 & 14,7 & 14,6 & 8,1 & 15,9 & 14,8 \\
\hline 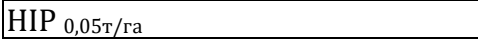 & 1,2 & 1,1 & 1,5 & 1,2 & 1,1 & 1,5 \\
\hline
\end{tabular}

При збиранні урожаю бульби сортуються на фракції (товарні великі, середні, середньо-дрібні та нетоварні - дрібні). По товарності та структурі урожаю сорту Імпала виділяються варіанти 3 використанням Фумару з гібереліном та Реастиму з гібереліном, сорту Загадка - розчину Біоглобіну та Реастиму з гібереліном табл. 10. 
Таблиця 9

Товарність картоплі молодої сорту Загадка, \%

\begin{tabular}{|c|c|c|c|c|c|c|}
\hline \multirow[b]{2}{*}{$\begin{array}{c}\text { Спосіб підготовки бульб до } \\
\text { висаджування }\end{array}$} & \multicolumn{3}{|c|}{ Пророщені } & \multicolumn{3}{|c|}{ Непророщені } \\
\hline & ì & $\stackrel{\dot{2}}{\stackrel{\text { n}}{2}}$ & $\underset{\dot{d}}{\dot{2}}$ & 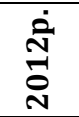 & $\stackrel{\dot{2}}{\stackrel{m}{\circ}}$ & ᄅे \\
\hline \multicolumn{7}{|l|}{ Свіжозібрані бульби: } \\
\hline $\begin{array}{l}\text { 1. Чотирикомпонентний } \\
\text { розчин (контроль)* }\end{array}$ & 70 & 71 & 72 & 72 & 72 & 72 \\
\hline $\begin{array}{l}\text { 2. Обробка водою (абсолютний } \\
\text { контроль) }\end{array}$ & 64 & - & - & 62 & - & - \\
\hline 3. 0,3 \% Потейтін & 71 & - & - & 73 & - & - \\
\hline 4. 2 & 74 & 75 & 75 & 74 & 73 & 76 \\
\hline $\begin{array}{l}\text { 5. Реастим (5 \%) + гіберелін } \\
(0,0005 \%)\end{array}$ & 78 & 81 & 82 & 80 & 81 & 80 \\
\hline Середнє по досліду & 71,4 & 76,0 & 75,7 & 72,4 & 74,9 & 76,0 \\
\hline $\mathrm{HIP}_{0}$ & 3,0 & 3,4 & 4,4 & 3,1 & 4,0 & 2,2 \\
\hline
\end{tabular}

Примітки: сорт нестабільно реагує на обробки: водою, Потейтіном.

Таблиця 10

Структура урожаю картоплі молодої сорт Імпала середнє за 2011-2014 рр. (пророщені)

\begin{tabular}{|c|c|c|c|c|}
\hline \multirow[b]{2}{*}{$\begin{array}{c}\text { Спосіб підготовки бульб } \\
\text { різного походження до } \\
\text { висаджування }\end{array}$} & \multicolumn{4}{|c|}{ Структура врожаю бульб, \% } \\
\hline & $\begin{array}{c}\text { Великі } \\
>80 \text { г }\end{array}$ & 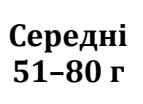 & $\begin{array}{l}\text { Середньо- } \\
\text { дрібні } \\
26-50 \text { г }\end{array}$ & $\begin{array}{l}\text { Дрібні } \\
<25 \text { г }\end{array}$ \\
\hline 1. Минулорічні бульби & 21,0 & 37,2 & 16,0 & 25,7 \\
\hline \multicolumn{5}{|c|}{ Свіжозібрані бульби: } \\
\hline \begin{tabular}{|l}
2. Чотирикомпонент- \\
ний розчин (контроль)*
\end{tabular} & 21,7 & 37,4 & 17,4 & 23,4 \\
\hline $\begin{array}{l}\text { 3. Обробка водою } \\
\text { (абсолютний контроль) }\end{array}$ & 0 & 12,6 & 21,4 & 16,0 \\
\hline $4.2 \%$ Біоглобін & 2,5 & 4,7 & 11,2 & 6,5 \\
\hline $\begin{array}{l}\text { 5. Фумар }(0,02 \%)+ \\
\text { гіберелін }(0,0005 \%)\end{array}$ & 22,0 & 38,2 & 17,3 & 22,4 \\
\hline $\begin{array}{l}\text { 6. Реастим (5 \%) + } \\
\text { гіберелін }(0,0005 \%)\end{array}$ & 24,5 & 39,2 & 14,9 & 21,4 \\
\hline $\begin{array}{l}\text { 7. Гумат калію }(0,5 \%)+ \\
\text { гіберелін }(0,0005 \%)\end{array}$ & 16,2 & 22,7 & 18,3 & 17,8 \\
\hline Середнє по досліду & 18,0 & 27,6 & 16,7 & 19,2 \\
\hline HIP $_{0,05, \%}$ & 1,0 & 1,6 & 1,0 & 1,0 \\
\hline
\end{tabular}

Примітки: сорт нестабільно реагує на обробку: водою, Біоглобіном, Гуматом калію. 
Літнє садіння минулорічними бульбами сприяє формуванню врожаю молодої картоплі наступного структурного складу: середні (37\%) дрібні (25,7\%) бульби, порівняно 3 вирощеними зі свіжозібраних бульб (застосування розчинів 3 передсадивної обробки: Фумар з гібереліном та Реастим з гібереліном) формується нижчий відсоток великих і середніх бульб та вищій дрібних. Пророщування свіжозібраних бульб перед садінням у двоурожайній культурі впливу на структуру урожаю картоплі молодої не має табл. 11.

Таблиця 11

\section{Структура урожаю картоплі молодої сорт Імпала} середнє за 2011-2014 рр. (непророщені)

\begin{tabular}{|l|c|c|c|c|}
\hline \multirow{2}{*}{$\begin{array}{c}\text { Спосіб підготовки } \\
\text { бульб різного } \\
\text { походження до } \\
\text { висаджування }\end{array}$} & $\begin{array}{c}\text { Селикі } \\
\text { > 80 г }\end{array}$ & $\begin{array}{c}\text { Середні } \\
\mathbf{5 1 - 8 0} \text { г }\end{array}$ & $\begin{array}{c}\text { Середньо- } \\
\text { дрібні } \\
\mathbf{2 6 - 5 0 ~ г ~}\end{array}$ & $\begin{array}{c}\text { Дрібні } \\
\text { <25 г }\end{array}$ \\
\hline \multicolumn{4}{|c|}{ Свіжозібрані бульби: } \\
\hline $\begin{array}{l}\text { 1. Чотирикомпонент- } \\
\text { ний розчин (контроль) }\end{array}$ & 20,5 & 33,5 & 21,5 & 24,5 \\
\hline $\begin{array}{l}\text { 2. Обробка водою } \\
\text { (абсолютний контроль) }\end{array}$ & 0 & 7,6 & 27,1 & 15,2 \\
\hline 3.2 \% Біоглобін & 2,5 & 4,4 & 11,6 & 6,5 \\
\hline $\begin{array}{l}\text { 4. Фумар (0,02 \%) + } \\
\text { гіберелін (0,0005 \%) }\end{array}$ & 22,6 & 35,8 & 20,8 & 21,9 \\
\hline $\begin{array}{l}\text { 5. Реастим (5 \%) + } \\
\text { Гіберелін (0,0005 \%) }\end{array}$ & 24,9 & 35,5 & 20,1 & 21,2 \\
\hline $\begin{array}{l}\text { 6. Гумат калію (0,5 \%) + } \\
\text { гіберелін (0,0005 \%) }\end{array}$ & 16,6 & 23,6 & 17,6 & 17,9 \\
\hline Середнє по досліду & 17,4 & 23,6 & 19,8 & 17,8 \\
\hline НІР о,05, & 1,1 & 1,3 & 0,8 & 1,1 \\
\hline
\end{tabular}

Примітки: сорт нестабільно реагує на обробку: водою, Біоглобіном, Гуматом калію.

Найбільший вихід товарних бульб сорту Загадка одержали у варіанті з використанням для пробудження свіжозібраних бульб розчину Реастиму з гібереліном (25\% - великих, $41 \%$ - середніх та $14 \%$ середньо-дрібних бульб) та варіанті 3 використанням Біоглобіну - $21 \%$ великих, $37 \%$ - середніх та $17 \%$ середньодрібних бульб - табл. 12. Аналогічною була і структура урожаю зі свіжозібраних непророщених бульб. Порівняно з контролем за 
даних варіантів підготовки садивного матеріалу формувався більший відсоток великих та середніх бульб 3 одночасним зменшенням середньо-дрібних та дрібних - табл. 13.

Таблиця 12

Структура урожаю картоплі молодої сорт Загадка середнє за 2012-2014 рр. (пророщені)

\begin{tabular}{|c|c|c|c|c|}
\hline \multirow[b]{2}{*}{$\begin{array}{c}\text { Спосіб підготовки } \\
\text { бульб до } \\
\text { висаджування }\end{array}$} & \multicolumn{4}{|c|}{ Структура врожаю бульб, \% } \\
\hline & $\begin{array}{c}\text { Великі } \\
>80 \text { г }\end{array}$ & $\begin{array}{l}\text { Середні } \\
51-80 \text { г }\end{array}$ & $\begin{array}{l}\text { Середньо- } \\
\text { дрібні } \\
26-50 \text { г }\end{array}$ & $\begin{array}{l}\text { Дрібні } \\
<25 \text { г }\end{array}$ \\
\hline \multicolumn{5}{|c|}{ Свіжозібрані бульби: } \\
\hline $\begin{array}{l}\text { 1. Чотирикомпонентний } \\
\text { розчин (контроль)* }\end{array}$ & 17 & 35 & 19 & 29 \\
\hline $\begin{array}{l}\text { 2. Обробка водою } \\
\text { (абсолютний контроль) }\end{array}$ & 0 & 6 & 15 & 12 \\
\hline 3. 0,3 \% Потейтін & 5 & 10 & 9 & 10 \\
\hline 4. $2 \%$ Біоглобін & 21 & 37 & 17 & 25 \\
\hline $\begin{array}{l}\text { 5. Реастим }(5 \%)+ \\
\text { гіберелін }(0,0005 \%)\end{array}$ & 25 & 41 & 14 & 20 \\
\hline Середнє по досліду & 16,8 & 25,6 & 14,7 & 18,9 \\
\hline HIP $_{0,05, \%}$ & 1,2 & 1,1 & 1,1 & 0,6 \\
\hline
\end{tabular}

Таблиця 13

Структура урожаю картоплі молодої сорт Загадка середнє за 2012-2014 рр. (непророщені)

\begin{tabular}{|c|c|c|c|c|}
\hline \multirow[b]{2}{*}{$\begin{array}{c}\text { Спосіб підготовки бульб } \\
\text { до висаджування }\end{array}$} & \multicolumn{4}{|c|}{ Структура врожаю бульб, \% } \\
\hline & $\begin{array}{l}\text { Великі } \\
>80 \text { г }\end{array}$ & $\begin{array}{l}\text { Середні } \\
51-80 \text { г }\end{array}$ & $\begin{array}{c}\text { Середньо- } \\
\text { дрібні } \\
26-50 \text { г }\end{array}$ & $\begin{array}{l}\text { Дрібні } \\
<25 \text { г }\end{array}$ \\
\hline \multicolumn{5}{|l|}{ Свіжозібрані бульби: } \\
\hline $\begin{array}{l}\text { 1. Чотирикомпонентний } \\
\text { розчин (контроль)* }\end{array}$ & 16 & 35 & 21 & 28 \\
\hline $\begin{array}{l}\text { 2. Обробка водою } \\
\text { (абсолютний контроль) }\end{array}$ & 0 & 7 & 14 & 13 \\
\hline 3. 0,3 \% Потейтін & 4 & 10 & 10 & 9 \\
\hline $4.2 \%$ Біоглобін & 22 & 37 & 15 & 26 \\
\hline $\begin{array}{l}5 \text { Реастим (5 \%) + } \\
\text { гіберелін }(0,0005 \%)\end{array}$ & 25 & 42 & 13 & 20 \\
\hline Середнє по досліду & 16,8 & 26,0 & 14,5 & 18,6 \\
\hline $\mathrm{HIP}_{0,05, \%}$ & 1,5 & 1,4 & 1,1 & 0,9 \\
\hline
\end{tabular}


Способи передсадивної підготовки свіжозібраних бульб до висаджування у двоурожайній культурі впливають на загальну кількість стандартних бульб у кущі - до 5 шт./кущ (на прикладі сорту Імпала з використанням Фумару з гібереліном та Реастиму 3 гібереліном). Середня маса бульб в кущі складає від 392 г до 421 г табл 14-15.

Таблиця 14

Маса товарних та нетоварних бульб сорту Імпала, г/кущ середнє за 2011-2014 рр. (пророщені)

\begin{tabular}{|l|c|c|}
\hline \multicolumn{1}{|c|}{$\begin{array}{c}\text { Спосіб підготовки бульб різного } \\
\text { походження до висаджування }\end{array}$} & $\begin{array}{c}\text { Урожайність } \\
\text { товарних } \\
\text { бульб з } \\
\text { куща, грам } \\
\text { 1. Минулорічні бульби }\end{array}$ & $\begin{array}{c}\text { Урожайність } \\
\text { нетоварних } \\
\text { бульб з }\end{array}$ \\
\hline Свіжа, грам
\end{tabular}

Таблиця 15

Маса стандартних та нестандартних бульб сорту Імпала, г/кущ середнє за 2011-2014 pp. (непророщені)

\begin{tabular}{|l|c|c|}
\hline $\begin{array}{c}\text { Спосіб підготовки бульб різного } \\
\text { походження до висаджування }\end{array}$ & $\begin{array}{c}\text { Урожайність } \\
\text { товарних бульб } \\
\text { 3 1 куща, грам }\end{array}$ & $\begin{array}{c}\text { Урожайність } \\
\text { нетоварних } \\
\text { бульб } \\
\text { з 1 куща, грам }\end{array}$ \\
\hline \multicolumn{1}{|c|}{ 1 } & 2 & 3 \\
\hline Свіжозібрані бульби: & \multicolumn{2}{|c|}{} \\
\hline $\begin{array}{l}\text { 1. Чотирикомпонентний розчин } \\
\text { (контроль) }\end{array}$ & 341,2 & 104,5 \\
\hline $\begin{array}{l}\text { 2. Обробка водою } \\
\text { (абсолютний контроль) }\end{array}$ & 58,2 & 21,7 \\
\hline 3. 2 \% Біоглобін & 52,5 & 18,0 \\
\hline
\end{tabular}


Закінчення таблиці 15

\begin{tabular}{|l|c|c|}
\hline \multicolumn{1}{|c|}{1} & 2 & 3 \\
\hline $\begin{array}{l}\text { 4. Фумар (0,02 \%) + гіберелін } \\
(0,0005 \%)\end{array}$ & 363 & 99,2 \\
\hline $\begin{array}{l}\text { 5. Реастим (5 \%) + гіберелін } \\
(0,0005 \%) .\end{array}$ & 381,2 & 100,7 \\
\hline $\begin{array}{l}\text { 6. Гумат калію (0,5 \%) + гіберелін } \\
(0,0005 \%)\end{array}$ & 247,2 & 76,5 \\
\hline Середнє по досліду & 240 & 70 \\
\hline НІР 0,05, грам
\end{tabular}

Примітки: сорт нестабільно реагує на обробку: водою, Біоглобіном, Гуматом калію.

Найбільша кількість бульб в кущі (сорт Загадка) сформувалась на ділянках варіантів 3 використанням розчину Біоглобіну та Реастиму з гібереліном - в середньому, перевищення контролю складає 1,1 і 1,4 шт./кущ (пророщені) та 0,7 і 0,8 шт./кущ (непророщені), відповідно.

Середня маса товарних бульб складала 398 та 430 г (варіант 5 та 7 пророщені) та 404 і 428 г (непророщені) відповідно, що на 60 і 92 г (пророщені) та 60 і 84 г (непророщені) перевищувало контроль - таблиця 16-17.

Таблиця 16

Маса товарних та нетоварних бульб сорту Загадка, г/кущ середнє за 2012-2014 рр. (пророщені)

\begin{tabular}{|l|c|c|}
\hline \multicolumn{1}{|c|}{$\begin{array}{c}\text { Спосіб підготовки бульб до } \\
\text { висаджування }\end{array}$} & $\begin{array}{c}\text { Урожайність } \\
\text { товарних } \\
\text { бульб з 1 } \\
\text { куща, грам }\end{array}$ & $\begin{array}{c}\text { Урожайність } \\
\text { нетоварних } \\
\text { булььб }\end{array}$ \\
\hline Свщжа, грам
\end{tabular}


Таблиця 17

Маса товарних та нетоварних бульб сорту Загадка, г/кущ середнє за 2012-2014 рр. (непророщені)

\begin{tabular}{|l|c|c|}
\hline \multicolumn{1}{|c|}{$\begin{array}{c}\text { Спосіб підготовки бульб до } \\
\text { висаджування }\end{array}$} & $\begin{array}{c}\text { Урожайність } \\
\text { товарних } \\
\text { бульб з 1 } \\
\text { куща, грам }\end{array}$ & $\begin{array}{c}\text { Урожайність } \\
\text { нетоварних } \\
\text { бульб з } \\
\text { куща, грам }\end{array}$ \\
\hline Свіжозібрані бульби: \\
\hline $\begin{array}{l}\text { 1. Чотирикомпонентний розчин } \\
\text { (контроль) }\end{array}$ & 344,0 & 133,7 \\
\hline $\begin{array}{l}\text { 2. Обробка водою (абсолютний } \\
\text { контроль) }\end{array}$ & 18,0 & 11,3 \\
\hline 3. 0,3 \% Потейтін & 131,7 & 48,7 \\
\hline 4. \% Біоглобін & 404,3 & 140,0 \\
\hline 5. Реастим (5 \%) + гіберелін (0,0005 \%) & 428,0 & 104,7 \\
\hline Середнє по досліду & 265,0 & 88,0 \\
\hline НІР 0,05, грам & 3,8 & 4,0 \\
\hline
\end{tabular}

Примітки: сорт нестабільно реагує на обробки: водою, Потейтіном

\section{Висновки}

За вирощування картоплі ранньої в ущільнених посівах найбільш доцільним ущільнювачем $\epsilon$ цибуля-шалот на зелене перо. Рослинуущільнювач слід висаджувати одразу після садіння картоплі (рекомендована густота рослин 55 тис. рослин / га) у її міжряддя на глибину $4-5 \mathrm{~cm}$ за схемою $140 \times 8-10 \mathrm{~cm}$ (густота рослин 80-85 тис. рослин / га) - рис. 19.

Вирощування картоплі ранньої у двоурожайній культурі має сортові особливості:

сорт Імпала: способи підготовки свіжозібраних бульб до висаджування у двоурожайній (повторній) культурі впливали на проходження рослинами фаз росту та розвитку. 3 використанням Фумару з гібереліном та Реастиму з гібереліном спостерігалося підвищення кількості стебел на 0,6-0,5 шт./кущ (пророщені) та на 0,7 шт./кущ (непророщені). Внаслідок цього зростала площа листків на 1,4-1,3 тис. м²/га (пророщені) та на 1,1-1,4 тис. м $^{2} /$ га (непророщені), відповідно. Крім того, суттєво підвищується урожай молодих бульб: порівняно 3 контролем приріст складав від 0,7 (Фумар 3 гібереліном) до 1,8 т/га (Реастим 3 гібереліном) за використання пророщення та 1,0 і 2,0 т/га за його відсутності, відповідно. За даних варіантів підготовки садивного матеріалу одержано найбільшу кількість стандартних бульб (до 5 шт./кущ) та 
найвищу середню масу бульб в кущі - 392 г (пророщені), 416 г (непророщені) відповідно. Сорт не стабільно реагує на обробку розчинами: Гумату калію, Біоглобіну.

Сорт Загадка: на проходження рослинами фаз росту і розвитку позитивно впливали певні поєднання хімічних речовин: 3 використання Біоглобіну та Реастиму з гібереліном спостерігалось підвищення кількості стебел на 0,2 і 0,4 шт./кущ (пророщені) та на 0,3 і 0,4 шт./кущ (непророщені), відповідно. Одночасно зросла площа листкової поверхні на 0,6 та 1,4 тис.м²/га (пророщені) і на 0,8 та 1,6 тис.м²/га (непророщені), відповідно. Встановлено і суттєвий приріст урожаю за даних варіантів порівняно до контролю - 0,6 i 1,6 т/га (пророщені) та 0,8 і 1,3 т/га (непророщені), відповідно.

Дані варіанти сформували найбільшу кількість та середню масу бульб у кущі, що склала 398 і 430 г (пророщені) та 404 і 428 г (непророщені), відповідно.

Сорт Загадка не реагує на обробку (пророщених та непророщених свіжозібраних бульб) водним розчином Гумату калію з гібереліном, нестабільно реагує на обробку розчином Потейтіном та обробку бульб водою (абсолютний контроль).

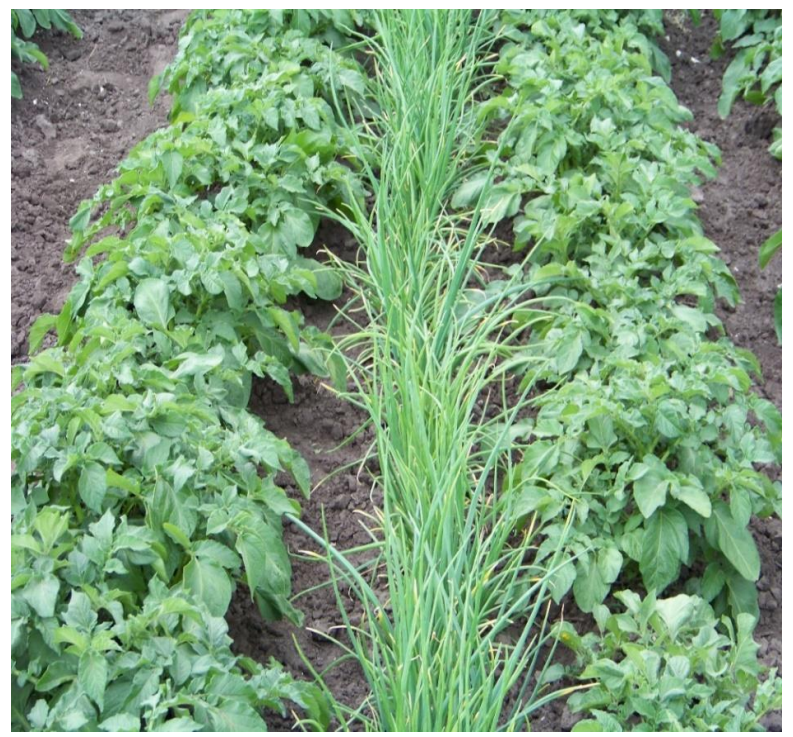

Рис. 19 Ущільнені посіви картоплі ранньостиглої в зоні північного Степу України 


\section{Список використаних джерел:}

1. Агрометеорологічні ресурси картоплі / за. ред. : Теслюка П. С. Київ : Урожай, 1992. 206 с.

2. Дегтярев В. Уплотненные и пожнивные посевы. Картофель и овощи. Москва, 1965. № 5. С. 30-33.

3. Сосунов В. Совместное выращивание огурцов с помидорами. Катофель и овощи. Москва, 1965. № 5. С. 34-35.

4. Сапожников В. Уплотненное использование земли. Картофель и овощи. Москва, 1961. № 4. С. 41-42.

5. Недбал Р. В. Вплив ущільнювачів на врожайність насіння листової петрушки. Таврійський науковий Вісник. Херсон, 2005. № 39. С. 167-172.

6. Дідух Н. О. Вирощування кукурудзи цукрової в ущільнених посівах у лівобережному Лісостепу України. Вісник Харківського державного аграрного університету ім. В. В. Докучаєва. Харків, 2013. № 9. C. 235-239.

7. Гарбовська Т. М. Вирощування квасолі овочевої як ущільнювача сільськогосподарських культур в умовах східного Лісостепу України. Овочівництво і баштанництво. 2015. № 61. С. 53-59.

8. Сыч 3. Д. Уплотненные посевы: реальная возможность повышения продуктивности. Овощеводство. Киев, 2015. № 12. C. 28-30.

9. Вітанов О. Д., Гарбовська Т. М., Щербина С. О., Урюпіна Л. М., Зелендін Ю. М., Чефонова Н. В. Біологічні особливості сортів квасолі овочевої та економічна ефективність її вирощування. Овочівнищтво і баштанництво. Вінниця, 2019. № 66. С. 47-54.

10. Приучуков Ф. Б. Агроэкологические основы интеркроппинга (поликультуры). Земледелие. 1995. № 2. С. 44-45.

11. Jacob, J., Shirmila, J., Sarada, S., Anu S. Role of Allelopathy in vegetables crops production. Allelopathy Journal. 2019. № 25 (2). P. 275-312.

12. 12. Valcheva, E., Popov, V., Marinov-Serafimov, P., Golubinova, I., Nikolov, B., Velcheva, I., Petrova S. A Case Study of Allelopathic Effect of Parsley, Dill, Onion and Carrots on the Germination and Initial Development of Tomato Plants. Ecologia balkanica. 2019. Vol. 11. P. 167-177.

13. Головко Ю., Пузік В. Алелотапатія і дизайн ландшафтних композицій. Інтродукція рослин: збірник наукових праць. 2003. № 1-2. С. 149-157.

14. Симагина Н. О. Аллелопатические свойства Гликогалофита Artemisia santonica L. Ученые записки Таврического национального университета им. В. И. Вернадского. 2006. Том 19 (58). № 4. С. 177-185. 
15. Бухаров А.Ф., Балеев Д.Н., Бухарова А. Р. Оценка адаптивности и стабильность проявления аллелопатической активности экстрактов из семян овощных сельдерейных культур. Вестник Алтайского государственного аграрного университета. 2011. № 3 (77). С. 36-39.

16. Гродзинский А. М. Аллелопатия в жизни растений. Киев : Наукова думка, 1965. 187 с.

17. Гнатюк Н. О. Оцінка алелопатичних властивостей насіння деяких видів ароматичних рослин. Інтродукція рослин. 2003. № 4. С. 109-113.

18. Юрчак Л. Д. Алелопатія в агробіоценозах ароматичних рослин. Київ. 2005. 250 с.

19. Матвеев Н. М. Аллелопатия как фактор экологической среды. Самара: Самарское книжное издательство, 1994. 204 с.

20. Кучко А. А., Власенко М. Ю., Мицьо В. М. Фізіологія та біохімія картоплі. Київ: Довіра, 1998. 335 с.

21. Лысенко Т. Д. за развитие культуры картофеля в засушливых районах. Овощеводство. 1939. № 1. С. 9-13.

22. Семенченко О. Л., Даніліна А. С. Вплив доз і способів внесення мінеральних добрив на врожайність картоплі ранньої. Бюлетень Інституту сільського господарства степової зони НААН України. 2012. № 3. С. 78-84.

23. Фаворов О. М., Котов А. Ф. Літнє садіння картоплі в колгоспах і радгоспах УРСР. Одеса. 1949. 90 с.

24. Теслюк П. С., Молоцький М. Я. Практичний порадник картопляра. Київ : «Кий». 1999. 268 с. 